\title{
Pengaruh Penambahan Air Perasan Jeruk Nipis (Cirrus aurantïfiolia) dalam Air Minum terhadap Tampilan Karkas Ayam Broiler
}

\author{
The Effect of Added Lime Juice (Citrus aurantiifolia) in Drinking Water on Broiler \\ Carcass Trait
}

\author{
Aditya Rakhamansyah, Warsono Sarengat, dan Teysar Adi Sarjana \\ Laboratorium Produksi Ternak Unggas, Fakultas Peternakan dan Pertanian \\ Universitas Diponegoro \\ Corresponding e-mail: bocahdani@gmail.com
}

\begin{abstract}
The experiment was conducted to determine the effect of lime juice addition on broiler carcass trait. The material used was 90 day old chick (DOC) broilers with an average weight of $38 \pm 0.1 \mathrm{~g}$. The experimental design applied was a Completely Randomized Design (CRD) with 3 treatments and 6 replications. Treatments were given since 21 days of age into the broilers drinking water which are T0 (drinking water without the addition of lime juice), T1 (drinking water added with $0.5 \%$ lime juice), and T2 (drinking water given $1 \%$ lime juice). Parameters measured were cut weight, carcass and abdominal fat percentage. The results showed that the addition of lime juice up to $1 \%$ in drinking water did not have a significant effect on carcass trait including cut weight, carcass weight and carcass percentage but were able to reduce the percentage of abdominal fat significantly when given $1 \%$ lime juice. The conclusions of the research was the addition of lime juice at the level of $1 \%$ can reduce broilers' abdominal fat without affecting carcass trait.
\end{abstract}

Key words: lime juice, broiler, carcass trait, abdominal fat

\begin{abstract}
ABSTRAK
Penelitian ini bertujuan untuk mengetahui pengaruh penambah air perasan jeruk nipis terhadap tampilan karkas ayam broiler. Materi yang digunakan yaitu 90 ekor day old chick (DOC) broiler dengan bobot rata-rata sebesar $38 \pm 0,1 \mathrm{~g}$. Rancangan yang digunakan pada penilitian ini adalah rancangan acak lengkap (RAL) 3 perlakuan dengan 6 ulangan. Perlakuan mulai diterapkan pada umur 21 hari. Air minum ayam broiler terdiri dari T0 (air minum tanpa tambahan perasan jeruk nipis), T1 (air minum yang ditambah 0,5\% perasan jeruk nipis), dan T2 (air minum yang ditambah $1 \%$ perasan jeruk nipis). Parameter yang diukur bobot potong, persentase karkas, potongan komersial dan lemak abdominal. Hasil penelitian menunjukkan bahwa penambahan perasan jeruk nipis sampai $1 \%$ dalam air minum tidak memberikan pengaruh nyata terhadap tampilan karkas meliputi bobot potong, bobot karkas dan persentase karkas namun mampu menurukan persentase lemak abdominal secara signifikan pada penambahan $1 \%$. Kesimpulan dari penelitian ini adalah penambahan air perasan jeruk nipis pada level $1 \%$ mampu menurunkan lemak abdominal tanpa mempengaruhi tampilan karkasnya.
\end{abstract}

Kata kunci: jeruk nipis, broiler, tampilan karkas, lemak abdominal

\section{PENDAHULUAN}

Ayam broiler merupakan ternak yang penting dalam memenuhi kebutuhan protein hewani masyarakat. Permintaan terhadap daging ayam semakin bertambah seiring dengan meningkatnya penghasilan dan kesadaran penduduk akan pentingnya protein hewani. Meningkatnya kesadaran masyarakat akan kebutuhan zat gizi menyebabkan konsumsi terhadap bahan makanan hewani meningkat. akan tetapi masyarakat masih banyak berpandangan bahwa mengkonsumsi ayam dapat menyebabkan berbagai penyakit, ini dikarenakan kandungan lemak daging ayam yang tinggi. Dengan begitu perlu adanya solusi dalam menghasilkan ayam broiler yang memiliki kandungan lemak yang rendah. Dengan menambahkan acidifier alami yang mudah didapatkan.

Acidifier adalah bahan alami atau sintesis yang berfungsi menjaga keseimbangan mikroba di dalam saluran pencernaan melalui pengaturan $\mathrm{pH}$ pada saluran pencernaan. Saluran pencernaan yang memiliki $\mathrm{pH}$ rendah akan menurunkan 
populasi bakteri patogen, sementara bakteri menguntungkan (bakteri asam laktat) dapat meningkat pertumbuhan dan perkembangannya, sehingga dapat meningkatkan kecernaan serta mengoptimalkan penyerapan nutrien dalam pakan (Huyghebaert et al., 2005). Penyerapan nutrien yang optimal akan mensintesis jaringan lebih banyak, yang akan mengakibatkan pertambahan bobot badan pada ternak.

Peningkatan bobot badan akan mempengaruhi bobot potong dan bobot karkas Pertumbuhan broiler yang cepat juga diikuti dengan pertumbuhan lemaknya yang cepat (Suprijatna, 2005). lemak abdomen terjadi karena energi yang merupakan hasil dari proses metabolisme zat gizi yang masuk ke dalam tubuh ayam melebihi tingkat kebutuhan yang diperlukan oleh tubuh itu sendiri, baik itu untuk hidup pokok maupun untuk berproduksi (Oktaviana et al., 2010). Timbunan lemak abdomen juga dapat dijadikan indikasi bahwa telah terjadi pemborosan pakan.

Hal tersebut dikarenakan lemak abdomen merupakan bagian yang tidak termanfaatkan maka perlu adanyanya acidifier yang berperan untuk menjaga keseimbangan saluran pencernaan sehingga pakan yang tidak dapa dirubah menjadi energi maka bisa di cerna dengan baik sehingga tidak menumpuk menjadi lemak abdominalAsam sitrat merupakan asam lemah yang mudah di gunakan. Asam sitrat juga mudah di metabolisme dihilangkan dari. penggunaan asam organik sudah di lakukan di dalam penelitian Asam organik adalah promotor pertumbuhan yang baik pada ternak domestik dengan pengurangan populasi mikroba usus dan meningkatkan status kekebalan pada ternak (Dibner, 2002). Penelitian penambahan asam sitrat sebesar $0,75 \%$ dalam ransum meningkatkan kualitas produksi unggas, pada broiler yang diberi $1,25 \%$ menunjukkan hasil yang lebih baik hingga dosis $3 \%$ asam sitrat.

Acidifier yang dipilih pada penelitian ini adalah jeruk nipis, Jeruk nipis dipilih karena mengandung asam sitrat 10 kali lebih banyak dibanding kandungan sitrat jeruk keprok, atau enam kali jeruk manis. jeruk nipis ( $C$. aurantifolia) mengandung asam sitrat $7 \%$, asam amino (triptofan, lisin), minyak atsiri (sitral, limonen, felandren, lemon kamfer, kadinen, gerani-lasetat, linalilasetat, aktilaldehid, nildehid) damar, glikosida, asam sitrun, lemak, kalsium, fosfor, besi, belerang vitamin B1 dan C (Khotimah, 2002).

Tujuan penelitian ini dilakukan untuk menguji manfaat asam sitrat alami melalui air perasan jeruk nipis sebagai acidifier untuk meningkatkan tampilan karkas ayam broiler serta menurunkan lemak abdominal. Hipotesis penelitian bahwa penggunaan asam sitrat dengan air perasan jeruk nipis sebagai acidifier mampu meningkatkan tampilan karkas ayam broiler dan menurunkan lemak abdominal.

\section{MATERI DAN METODE}

Penelitian dilaksanakan selama 1 bulan di Laboratorium Produksi Ternak Unggas, Fakultas Peternakan dan Pertanian Universitas Diponegoro, Semarang. Materi yang digunakan dalam penelitian ini adalah ayam broiler strain Lohman unsexed dengan jumlah 90 ekor dan dipelihara mulai umur 1 hari dengan BB 38+0,1 g/ekor. Pada umur 21 hari ayam broiler mulai diberikan perlakuan. Pemeliharaan dilakukan selama 35 hari dengan hasil bobot rata-rata akhir 501,11 g $(\mathrm{CV}=0,28 \%)$.

Pakan starter yang digunakan adalah "BR1-CP511 dan diberikan sampai umur 14 hari sedangkan pada fase finisher menggunakan pakan "201-C" (kandungan nutrisi ransum disajikan pada Tabel 1) air perasan jeruk nipis yang ditambah dengan $1000 \mathrm{ml}$ air diberikan pada pagi hari dan sebagian lagi pada sore hari. Pakan dan air minum diberikan ad libitum.

Penelitian menggunakan rancangan acak lengkap (RAL) dengan 3 perlakuan (T0, T1, T2) dan 6 ulangan, Perlakuan yang diberikan selama penelitian adalah : 
T0 : Air minum (tanpa air perasan Jeruk Nipis)

$\mathrm{T} 1$ : Air minum $+0,5 \%$ perasan Jeruk Nipis ( $5 \mathrm{ml}$ air jeruk nipis dalam $1000 \mathrm{ml}$ air minum)

$\mathrm{T} 2$ : Air minum $+1 \%$ perasan Jeruk Nipis (10 ml air perasan jeruk nipis dalam $1000 \mathrm{ml}$ air minum)

Prosedur penelitian meliputi tahap persiapan kandang dan persiapan peralatan. Tahap persiapan kandang dilakukan dengan menyiapkan kandang dan membersihkannya dengan melakukan pengapuran dan pemberian desinfektan. Tahap menyiapkan peralatan yaitu dengan menyiapkan peralatan yang digunakan yang kemudian dibersihkan dan diberi desinfektan. Persiapan air perasan jeruk nipis, air perasan jeruk nipis dibuat dengan cara memeras menggunakan alat peras yang terbuat dari plastik, air perasan kemudian diletakkan di dalam botol plastik sebelum digunakan dan disimpan di dalam lemari es. Pemerasan jeruk nipis dilakukan setiap dua hari sekali untuk diberikan selama dua hari. Jeruk nipis didapatkan dari pohon jeruk nipis yang ada di Ungaran, Jawa Tengah dengan umur tanam 30 minggu dan berdiameter $4 \mathrm{~cm}$.

Tabel 1. Kandungan nutrisi ransum

\begin{tabular}{lll}
\hline Parameter & Perlakuan & \\
& BR1-CP5111 & 201-C2 \\
\hline KadarAir (\%) & 13,0 & 13,0 \\
EM (kcal/kg)3 & 3.448 & 3.448 \\
Protein (\%) & 23 & 20 \\
Lemak (\%) & 5,0 & 5,0 \\
Serat (\%) & 5,0 & 5,0 \\
Abu (\%) & 7,0 & 8,0 \\
Kalsium (\%) & 0,9 & 0,9 \\
Fosfor (\%) & 0,6 & 0,6 \\
KadarAir (\%) & 13,0 & 13,0 \\
EM (kcal/kg)2 & 3.448 & 3.448 \\
Protein (\%) & 23 & 20 \\
Lemak (\%) & 5,0 & 5,0 \\
\hline Keman
\end{tabular}

Keterangan: ${ }^{1}$ : Label kandungan pakan BR1-CP511 PT. Charoen Pokphand dan kandungan pakan 201C PT. Goldcoin Indonesia Indonesia 2 : Perhitungan Rumus Bolton sebagaimana dalam Sugiharto et al. (2017)
Tahap perlakuan dan tahap analisis setiap unit percobaan diisi 5 ekor ayam broiler. Parameter yang diamati yaitu tampilan karkas ayam broiler meliputi bobot karkas, persentase karkas dan lemak abdominal. Estimasi kalkulasi konsumsi asam sitrat yang terkandung dalam air minum dilakukan berdasarkan asumsi standar konsumsi air/ekor/hari dan kandungan asam sitrat sebesar 5,8 \% / $100 \mathrm{ml}$ (Hasanudin et al., 2013).

Tabel 2. Konsumsi asam sitrat berdasarkan level pemberian

\begin{tabular}{cc}
\hline $\begin{array}{c}\text { Perlakuan } \\
\text { penambahan jeruk } \\
\text { nipis (\%) }\end{array}$ & $\begin{array}{c}\text { Konsumsi asam } \\
\text { sitrat } \mathrm{g} / \mathrm{l}\end{array}$ \\
\hline 0,00 & 0,00 \\
0,05 & 0,08 \\
1,00 & 0,15 \\
\hline
\end{tabular}

Data yang diperoleh dianalisis ragam dengan menggunakan dengan program SAS 9.1 (Statistical Analysis System). Data yang menunjukan perbedaan signifikan antar perlakuan di uji lanjut dengan DMRT (Duncan Multiple Range Test) dengan taraf $5 \%$.

\section{HASIL DAN PEMBAHASAN}

Penelitian penggunaan jeruk nipis sebagai acidifier pada air minum broiler menunjukkan hasil seperti tertera pada Tabel 3. Penambahan air perasan jeruk nipis tidak berpengaruh terhadap bobot potong dan persentase karkas namun siginifikan menurunkan persentase lemak abdominal pada level $1 \%$.

\section{Pengaruh Penambahan Jeruk Nipis terhadap Bobot Karkas}

Berdasarkan Tabel 3. Pemberian jeruk nipis dengan level $0,5 \%$ dan $1 \%$ belum memberikan pengaruh nyata terhadap bobot karkas Hal ini disebabkan karena kadar pemberian asam sitrat pada air minum jauh lebih rendah dibanding penelitian (Sibrani et al., 2014) pada kisaran 0,15- 0,20 \% dapat meningkatkan bobot karkas dan lemak abdominal pada ayam broier. 
Tabel 3. Rerata, bobot potong, persentase karkas dan persentase lemak abdominal

\begin{tabular}{lcccc}
\hline Parameter & \multicolumn{3}{c}{ Perlakuan } & Rataan \\
\hline & T0 & T1 & T2 & \\
\hline Bobot karkas (g) & 674 & 586 & 652 & 637 \\
persentase karkas(\%) & 55.82 & 53.93 & 53.17 & 54.30 \\
Persentase lemak & $0.42^{\mathrm{a}}$ & $0.10^{\mathrm{b}}$ & $0.09^{\mathrm{c}}$ & 0.20 \\
abdominal (\%) & 244 & 213 & 235 & \\
Rataan & & & \\
\hline
\end{tabular}

Keterangan: *Superskrip yang berbeda pada baris yang sama menunjukkan perbedaan nyata $(\mathrm{P}<0,05)$.

Bobot potong dipengaruhi oleh pertambahan bobot badan, sedangkan pertambahan bobot badan dipengaruhi oleh asupan nutrien. Rendahnya bobot potong sejalan dengan konsumsi ransum yang non signifikan, dengan tidak berpengaruhnya pemberian jerik nipis terhadap konsumsi ransum maka asupan nutrien bagi ayam broiler menurun sehingga bobot potong menurun. Hasil ini sesuai dengan penelitian yang telah dilakukan sebelumnya yang menyatakan bahwa pertambahan bobot badan juga sangat dipengaruhi oleh asupan nutrien dan pencernaan di dalam tubuh ternak, dimana semakin baik pencernaan dan penyerapan nutrien maka akan memberikan pertambahan bobot badan yang baik dan secara tidak langsung akan memberikan bobot potong yang tinggi pula (Soeparno, 2006).

Karkas merupakan bagian tubuh yang menentukan dalam produksi ayam pedaging. Produksi karkas berhubungan erat dengan bobot badan dan besarnya karkas ayam pedaging yang bervariasi. Bobot potong pada penelitian ini sebesar 959-1140 dan bobot karkas sebesar 586-674 dengan demikian pemberian jeruk nipis tidak memberikan pengaruh yang nyata terhadap bobot potong dan bobot karkas dengan tidak terpengaruhnya bobot potong demikian juga dengan bobot karkas yang dihasilkan karena bobot potong sejalan dengan bobot karkas. Hal ini sesuai dengan pendapat (Sibarani et al., 2014) bahwa bobot potong berbanding lurus dengan bobot karkas semakin tinggi bobot potong mak a tinggi pula berat karkas yang didapat karena persentase karkas dapat meningkat disebabkan oleh pencernaan pakan dan penyerapan nutrisi pakan yang meningkat pada ayam broiler dan sebaliknya rendahnya berat potong maka rendah pula bobot karkas ayam pedaging.

Capaian bobot karkas pada penelitian ini diduga disebabkan oleh konsumsi pakan yang non signifikan. Hal ini menunjukkan bahwa penambahan jeruk nipis tidak berpengaruh terhadap konsumsi. Hasil ratarata konsumsi pada ketiga perlakuan yaitu sebesar 2.549 g. Hal ini sesuai dengan hasil penelitian yang menyatakan bahwa penambahan acidifier sampai $1 \%$ tidak berpengaruh terhadap konsumsi dan bobot potong (Nugroho et al., 2016).

\section{Pengaruh Penambahan Jeruk Nipis terhadap Persentase Berat Karkas}

Berdasarkan Tabel 3 dapat diketahui bahwa pemberian air perasan jeruk nipis tidak berpengaruh terhadap potongan karkas komersil. dengan penambahan acidifier asam sitrat belum mampu meberikan pengaruh yang nyata. Hal ini disebabkan tidak adanya perubahan pada saluran pencernaan sehingga bobot karkas yang di hasilkan kecil hal ini sesuai (Sibarani et al., 2014) persentase karkas dipengaruhi oleh saluran pencernan dan bagian adible portion seperti kepala,leher dan kaki. Dampak asam sitrat yang memiliki peranan dalam mempercepat kondisi asam pada proventrikulus dan ventrikulus. Proses pencernaan protein pada unggas dimulai dalam proventrikulus. Asam sitrat membantu dalam proses penurunan $\mathrm{pH}$ pada saluran pencernaan pada bagian proventrikulus dan ventrikulus, Asam sitrat juga berperan mendukung perkembangan mikroba menguntungkan dan menekan mikroba pathogen sehingga berdampak pada kesehatan saluran pencernaan yaitu 
peningkatan fungsi saluran pencernaan dalam mencerna dan menyerap nurtien utamanya protein (Nugroho, 2016).

Persentase bobot karkas merupakan perbandingan bobot karkas dengan bobot hidup, sehingga bobot hidup yang besar akan diikuti pula oleh bobot karkas yang besar pula, dan sebaliknya. Pada bobot hidup yang tidak berbeda umumnya persentase karkas tidak berbeda. Dari hasil penelitian ini menunjukan persentase karkas sebesar 54$55 \%$ nilai ini masih di bawah penilitian (Subekti, 2007) yaitu sebesar 72,98-76,26\%.

\section{Pengaruh Penambahan Jeruk Nipis terhadap Persentase Lemak Abdominal}

Pemberian jeruk nipis dengan taraf $1 \%$ menunjukkan penurunan pada perlakuan T2 dimana lemak abdominal yang dihasilkan hanya $0,09 \%$. Asam organik berupa asam sitrat dapat menembus dinding sel bakteri dan mengganggu fisiologi normal beberapa jenis bakteri, sehingga akan menekan $\mathrm{pH}$ saluran pencernaan berkisar antara 5-6 dan meningkatkan kecernaan pakan yang dapat menurunkan pembentukan energi selain itu meningkatnya tampilan BAL. Rendahnya persentase lemak abdominal pada ayam broiler yang mendapat perlakuan ransum silase yang banyak mengandung asam organik, khususnya asam laktat yang tinggi (tampilan bakteri asam laktat) akan menghambat pembentukan energi khususnya glikolisis yang mengakibatkan penurunan trigliserida dan asetil CoA yang merupakan komponen penting dalam biosintesis lipida tubuh, termasuk juga lemak abdominal sebagai deposit lemak dalam tubuh ayam, asam laktat ini akan menyebabkan suasana lingkungan usus halus menjadi relatif lebih asam (Ihsan, 2006). Oleh karena itu penambahan perasan jeruk nipis dengan konsentrasi asam organic berupa asam sitrat dengan taraf hingga 1\% mampu menurunkan persentase lemak abdominal.

Kecilnya bobot lemak abdominal sejalan dengan kecilnya bobot badan akhir yang diperoleh dari hasil penelitian. Hal ini sesuai dengan Gultom et al. (2012) yang menyatakan bahwa berat lemak abdominal cenderung meningkat dengan bertambahnya berat badan, demikian sebaliknya jika bobot badan akhir kecil maka berat lemak abdominal juga kecil sehingga persentasi lemak abdominal juga kecil.

\section{KESIMPULAN}

Penambahan jeruk nipis dalam air minum pada level 0,5 dan $1 \%$ belum mampu memperbaiki tampilan karkas namun mampu menurunkan lemak abdominal.

\section{DAFTAR PUSTAKA}

Dibner, P. B. 2002. Use of organic acid as a model to study the impact of gut microflora on nutrition and metabolism. Journal of Applied Poultry Research. 11(4): 453-463.

Huyghebaert, N., Vermeire, A. and Remon, J. P. 2005. Alternative method for enteric coating of HPMC capsules resulting in ready-to-use entericcoated capsules. European Journal of Pharmaceutical Sciences. 21(5): 617623. doi: 10.1016/j.ejps.2004.01.002.

Ihsan, F. N. 2006. Persentase bobot Karkas, Lemak Abdomen dan Organ dalam Ayam Broiler dengan Pemberian Silase Ransum Komersial. Journal Pertanian IPB. 18 (4): 53-67.

Khotimah, K. 2002. Pengaruh Ekstrak Jeruk Nipis (Citrus aurantifolia) dan Metode Pengolahan pada Kualitas Daging Broiler. Biotechnology Center Journal. 8(4): 56-71.

Nugroho, T. S., Wahyuni, H. I. and Suthama, N. 2016. Acidifier terhadap kecernaan protein dan bobot badan akhir pada itik jantan lokal. Agromedia. 34 (2): 49-53. 
Sibarani, J., V. D. Yunianto, L. D. Mahfudz. 2014. Persentase karkas dan non karkas serta lemak abdominal ayam broiler yang diberi. Animal Agriculture Journal. 3(2): 273-280.

Soeparno. 2006. Ilmu dan Teknologi Daging. 1st edn. Yogyakarta: Gadjah Mada University Press.

Subekti, K, S. 2007. Kualitas Karkas (Berat Karkas, Persentase Karkas Dan Lemak Abdomen) Ayam Broiler yang Diberi Kombinasi CPO (Crude Palm Oil) dan Vitamin C (Ascorbic Acid) dalam Ransum sebagai Anti Stress Carcass, Development. 134 (4): 635 646.

Suprijatna, R. 2005. Ilmu Dasar Ternak Unggas. 2nd edn. Jakarta: Penebar Swadaya.
Sutrisno, V. D., Yunianto and N. Suthama. 2013. Kecernaan Protein Kasar dan Pertumbuhan Broiler yang diberi Pakan Single Step Down dengan Penambahan Acidifier Asam Sitrat. Journal Animal Agriculture. 2 (3):4860 .

Sugiharto, S., T. Yudiarti and I. Isroli. 2017. Effects of Feeding Cassava Pulp Fermented with Acremonium Charticola on Growth Performance, Nutrient Digestibility and Meat Quality of Broiler Chicks. Journal of Animal Science, South African. 47 (2): $130-138$

Siswohardjono, W. 1982. Beberapa metode pengukuran energi metabolis bahan makanan ternak pada itik. Institut Pertanian Bogor. Bogor. 